\title{
Gender and Ideology: For a Marxist Critique of the Ideology of Gender
}

\author{
Nildo Viana
}

Brazil

\begin{abstract}
The purpose of this paper is to discuss the issue of gender ideology in a critical and Marxist perspective. Criticism of the gender ideology is now a must, as well as present their social roots and their relationship to a particular historical period. Based on the critical analysis of the work of Joan Scott and his inspiring sources, especially Bourdieu, it seeks to show the ideological roots of gender conception.
\end{abstract}

Keywords: Gender, Ideology, category, Marxism, Poststructuralism, domination, sex.

The present paper aims to discuss the issue of gender ideology. We won't do an archeology of genre term, as some have done ${ }^{1}$,nor will pursue its etymological roots, nor its past uses, but only its recent use and its ideological character. The critique of gender ideology is, nowadays, a necessity as well as present its social roots and its bond with a certain historical period.

Before we begin, let's clarify what we mean by ideology, since this is a polysemic term. Here we use the Marxist conception of ideology ${ }^{2}$, according to which it is a systematization of false consciousness, that is, a illusory thinking system. Ideology is a systematic way of false consciousness produced by the ideologists. What we term as gender ideology is the conception that places the construct "gender" as a fundamental term of the analysis of the issue of women and even of society as a whole.

We won't present here the most diverse works that discuss and use the construct "gender".We will elect one of the most cited and influential works on this issue for analysis, although other references are made throughout this text. It is the text of the historian Joan Scott ${ }^{4}$, Gender: A Usefull Category of Historical Analysis. Joan Scott presents in her text an overview of different conceptions of feminist thought and of the use of the construct (which she denominated category) genre. The various concepts are presented descriptively, with superficial observations, and the author's point of view is presented peripherally, with a minimum contribution to the discussion around the issue that is proposed to treat.In fact, this defect to take long descriptions of feminist conceptions, consisting of all or almost all of the text, is quite common and is repeated in Scott's article. She states that the term gender in its most recent use occurred among American feminists, "who wanted to insist on the fundamentally social quality of distinctions based on sex". This use was aiming to reject biological determinism that would be implicit in the use of the terms "sex" and "sexual difference". The term gender would present a relational view and would present men and women in reciprocal terms, preventing the separate study of both. But the author points out that more important than that is that gender "was a term offered by those who claimed that women's scholarship would fundamentally transform disciplinary paradigms" ${ }^{\text {. }}$. A new methodology and epistemology would be with the term gender, giving it meaning. However, this position did not come right away:

For the most part, the attempts of historians to theorize about gender have remained within tradicional social scientific frameworks, using longstanding formulations that provide universal causal explanations. These theories have been limited at best because they tend to

\footnotetext{
${ }^{1}$ Stolke, 2004.

2 Marx and Engels, 1991.

${ }^{3} \mathrm{~A}$ constructor is a false concept, and this is a correct expression of reality, while that is its distorted expression. See in Viana, 2007.

${ }^{4}$ Scott, 1986

${ }^{5}$ Scott, 1986, p. 1054
} 
contain reductive or overly simple generalizations that undercut not only history's disciplinary sense of the complexity of social causation but also feminist commitments to analyses that will lead to change. ${ }^{6}$

After that, the author criticizes the descriptive uses of those who use the term gender, as well as analyzes the feminist conceptions starting from the perspective of the origin of patriarchy, of Marxism, until reach the post-structuralism and the American and British approach of "relation of object". She makes some pertinent criticisms of some of these conceptions, but is rather superficial and does not connect more effectively with her own conception. However, what interests us here is precisely Scott's position. In this context, it is crucial her definition of gender:

My definition of gender has two parts and several subsets. They are interrelated but must be analyticallydistinct. The core of the definition rests on an integral connection between two propositions: gender is a constitutive elemento of social relationships based on perceived differences between the sexes, and gender is a primary way of signifying relationships of power. Changes in the organization of social relationships always correspond to changes in representations of power, but the direction of change is not necessarily one way. 7

According to Scott, this definition involves four related elements: 1) the culturally available symbols evoke symbolic representations; 2 ) there are normative concepts that present interpretations regarding the meaning of the symbols, in order to reduce and contain their metaphoric possibilities; 3 ) the new conception task is to overcome the notion of fixity and timelessness of the binary gender representation, revealing its connection with politics, with the institutions and social organization; 4) The subjective identity or the "gendered identities" are built, and it's needed to relate it to "a range of activities, social organizations, and historically specific cultural representations" ${ }^{\text {" }}$. She reveals the key to her conception (Scott, 1986, p. 1069):

The first part of my definition of gender consists, then, of all four of these elements, and no one of them operates without the others. Yet they do not operate simultaneously, with one simply reflecting the others. A question for historical research is, in fact, what the relationships amont the four aspects are. The sketch I have offered of the process of constructing gender relationships could be used to discuss class, race, ethnicity, or, for that matter, any social process. My point was to clariy and specify how one needs to think about the effect of gender in social and institutional relationships, because this thinking is often not done precisely or sistematically. The theorizing of gender, however, is developed in my second proposition: gender is a primary field within which or by means of which power is articulated. Gender is not the only field, but it seems to have been a persistent and recurrent way of enabling the signification of power in the West, in Judeo-Christian as well as Islamic tradicions.

Thus here we have a particular ideology of genre that will be widely used by researchers of various human sciences and become a great reference, both in academic thinking in this area as of feminist thought. Thereby, this ideology arises of the refusal of biological determinism, of essentialism, and ends up proposing a paradigmatic transformation, presenting gender as a cultural construction and is in the founder field of power relations. This conception is ideological, that is, false, although, like every ideology, has moments of truth.

The refusal of biologism is important and necessary, however, when extrapolating this and presenting a rejection of "biological" (we would say, of corporeality and its importance) - although this was not explicitly stated, but it was practiced in the rest of the speech -, we have an ideological production. The social status of women in modern society is not exclusively derived from its physical/organic constitution and this is true, but is false from there to deny its existence or relation to this process. Obviously this will be the starting point for other ideologies even more misleading and bordering the absurd $^{9}$. The criticism of biologism, with regard to women's issues, moreover, is nothing new as it

\footnotetext{
${ }^{6}$ Scott, 1986 , p. 1055 .

${ }^{7}$ Scott, 1986, p. 1067.

${ }^{8}$ Scott, 1986, p. 1068 .

${ }^{9}$ The most explicit example of this ideological exasperation is Butler's thesis (2003), according to which sex is an effect of gender and society is based on "compulsory heterosexuality". That is, the determinant is the genre
} 
was born with Simone de Beauvoir ${ }^{10}$ in the 40 s of the 20 th Century and contemporary references add nothing and not go beyond the level presented by her, unless in a retrograde direction.

What she denounces in the other approaches is precisely what she does. She provides a universal causal explanation and held "reductive generalizations" and "overly simple". The determinism of gender is an ideological creation not only simplistic, but dogmatic, as it does not question and reflect on its own fundamentals.It is a determinism and a reductionism. And it is nonetheless revealed the disregard of historical materialism or, as is common, reduce it to more simplistic and dogmatic formulations, ie exchange it for what it's called "vulgar Marxism", far short of Marx.

However, the most problematic element of Scott's conception is in her pursuit of paradigmatic transformation, which is based on the idea that gender is the primary way to give meaning to the relations of power. The basis of such a theory is not held anywhere. References to Eve and Mary (Christian tradition),or any stereotype of women, outside the context in which it occurs, not establish nothing. The quotes of thinkers considered representatives of conservative thought, contrary to the French Revolution, as Burke, Bodin, among others, can not be generalized, if only because it is a critique of the Enlightenment and the bourgeois revolution of pre-bourgeois point of view. And it is nonetheless interesting as several women authors derive their ideas in the speeches of other women authors (or men authors, in rare cases) and not in concrete reality ${ }^{11}$. These conceptions are based on a unquestioned and unquestionable, that is, a dogma, which reveals a metaphysical abstraction and that does not explain anything. Taking the specific case of Scott, we have gender as "primary field" in which or through which "power is articulated". In addition to the statement, no justification, other than a brief reference to the sociologist Pierre Bourdieu. The genre here is a priori unquestioned, a dogma, without any justification.

The term gender is a metaphysical abstraction when seeking to transform it from category to concept $^{12}$, and so loses all its value. And this is even more serious when one want to put it as the determination of power relations. Obviously, no substantiated reasons is given for such priority to "gender" while instituting concept of social reality and power relationships. The author is content to appeal to Bourdieu and his reflections. Bourdieu condemns the non-historicity("naturalization", that is, make natural, something that is history), and at the same time does it. This is due to the fact that he never performs an analysis of the concrete reality of capitalist society, but purely presents his metaphysical abstractions about symbolic power, accompanied by his empiricism or its ideology of "fields" which serves as a model to think the "masculine domination ${ }^{13}$ ", an undue extrapolation. In Bourdieu's approach, the metaphysical abstraction meets the empirical that comes to confirm it, creating a dichotomous but homologous vision where isolated incidents of all serve as examples of metaphysical abstractions of symbolic violence and the like.

One can not think man (male gender) and women (female gender) as arbitrary cultural constructions. The representations, real or illusory, according to $\mathrm{Marx}^{14}$, are given from concrete social relations.

(cultural building) and not sex (organism) and the dominant sexual practices, heterosexuality, is compulsory, product of power relations, according to his inspiration in Foucault. This hyper culturalist thesis does not realize that cancels itself and falls into many contradictions.If it's the genre that produces sex ("woman has no sex", according to the epigraph of Irigaray used by Butler) then it is merely a cultural construction. So what's the problem? In what a cultural construction is better than the other? The answer is provided in the second thesis, the thesis of "compulsory heterosexuality" (not to mention the "phallocentrism"...). If heterosexuality is compulsory, then people are forced to be heterosexual, which means they are not naturally so. But if they are forced to be heterosexuals then it is because they are naturally homosexuals... an inversion (gender determines sex) is complemented by other (normal and natural is homosexuality...). This conception, besides having no basis in concrete reality, ends up falling into essentialism and biologism that it intended to fight (Only reverses/exchange heterosexual by homosexual essence and the sole basis for such essentialism can only be biological... After all, for what reason, other than biological, people would naturally be homosexual?).

${ }^{10}$ Beauvoir, 1978.

${ }^{11}$ Scott,1986; Stolke, 2004; Butler, 2003.

${ }^{12} \mathrm{~A}$ category is a resource without mental existence in the concrete reality, while a concept is an expression of reality therefore has concreteness. The expression "gender", as relationship, cause, effect, space, right, left, etc., falls within the first type, and to move to the second type must have an increase of something real, concrete (Viana, 2007).

${ }^{13}$ Bourdieu, 2002.

${ }^{14}$ Marx and Engels, 1991. 
Everyday representations and ideologies about female gender (and male gender), are not arbitrary products of "culture" or "power", these two metaphysical entities that dominate the anthropological contemporary discourse or post structuralist, whereas both culture and power of this ideology appears as something non-historical, indeterminate, asocial. The perception of the female gender consists historically and socially, but it's needed to discuss in which historical period and social context it occurs, as well as understand what is the class position of whom presents it. Let's see what Bourdieu says:

The divisions constitutive of the social order and, more precisely, the social relations of domination and exploitation that are instituted between the sexes thus progressively embed themselves in two different. classes of habitus, in the form of opposed and complementary bodily hexis and principles of vision and division which lead to the classifying of all the things of the world and all practices according to distinctions that are reducible to the male/female opposition. It falls to men, who belong on the side of all things external, official, public, straight, high and discontinuous, to perform all the brief, dangerous and spectacular acts which, like the sacrifice of the ox, ploughing or harvesting, not to mention murder or war, mark breaks in the ordinary course of life; women, by contrast, being on the side of things that are internal, damp, low, curved and continuous, are assigned all domestic labour, in other words the tasks that are private and hidden, even invisible or shameful, such as the care of the children or the animals, as well as all the external tasks that are attributed to them by mythic reason, that is to say, those that involve water, grass and other green vegetation (such as hoeing and gardening), milk and wood, and especially the dirtiest, most monotonous and menial tasks. 15

This quotation can be an example to analyze Bourdieu's procedure and its risks. First, we have a generalization: on one side "men", on the other, "women". Men, according to Bourdieu, are on the official side, of the right. All the men? The proletarians?The lumpen proletarians?The peasants?And women are all on the other side, thus there is no woman who holds power, that is in the state, etc. Women often are left with the dirty work, they take care of children. The women of the bourgeoisie do this? They do not hire other women to do it for them? In this approach, it seems like domestic workers work only for men, and the women of the bourgeoisie care for children, working in "monotonous and menial tasks". We do not know which country and epoch refers Bourdieu. He refers to an abstract-metaphysical world that does not exist concretely. "Women", in the plural and in general, has as task the "invisible, shameful"work, such as child care. Ora, Only from certain values that caring for children is "shameful", as well as other examples cited by Bourdieu, ie, humility, shame, etc., is not an attribute of activities but a valuation or devaluation of activities. ${ }^{16}$

In Bourdieu's analysis, phenomena such as social classes, values, capital accumulation, class struggle, etc., do not exist. The capitalist domination and the mercantile, competitive and bureaucratic world also do not exist in his approach. The "masculine domination" to Bourdieu has a structural homology to the various "camps" that he says exist in reality (artistic field, political field economic field scientific field etc. $)^{17}$ and so has the same fantastic isolation and similar logic, since Bourdieu was able to invent a "male illusio"18. But here doesn't fit a general critique of Bourdieu's sociology, that we'll do another time, but point out that his methodological procedure and his approach to the issue of women is tied to his abstract-metaphysical building, or ideological.

Thus, Scott complement to her analysis appealing to Bourdieu does not hold. But it is nonetheless interesting this appeal and how a metaphysical approach to the genre in Scott can be supplemented with other metaphysical approach, Bourdieu's approach. The rejection of all or reducing it to a sector of reality, arbitrarily chosen as "essential", since there was no justification, is a post-structuralist procedure reproduced by Scott and by gender ideologues.

\footnotetext{
${ }^{15}$ Bourdieu, 2002, p. 30.

${ }^{16}$ About the values and process valuation and its social character, check Viana, 2008.

${ }^{17}$ For a critical and distinct analysis of the analysis presented by Bourdieu about the fields, see Viana, $2015 \mathrm{a}$.

${ }^{18}$ The illusio is an expression originally used by Bourdieu to portray the "art of fetishism", in which agents of the artistic field endow value to works of art and transform them into fetishes (Bourdieu, 1996). It is a great extrapolation use this expression to speak of "masculine domination".
} 
We can conclude this analysis of the construct gender putting his abstract-metaphysical character, coming from the culturalist fad derived from post-structuralism ${ }^{19}$, just is a word used to uses and abuses, but that does not explain anything and does not lend itself to the struggle for social transformation because instead of unmasking power, hides. The gender construct is a unit of an ideological discourse. This ideological discourse or perform a fantastic isolation of relations between the sexes or considers such relations as founders of the social, or, as they say, power or, even, the power conceived metaphysically goes on to explain such relations. Thus, culture and power are transformed into metaphysical abstractions that come to explain and determine everything. In this last case, the indeterminate (culture, power) becomes the determinant of social relations, and this ideology that explains nothing becomes hegemonic in certain circles. In the first case, relations between the sexes (of "gender") are determinant, though never substantiated the source of this determination. That's why the work of Bourdieu is well received by some of the genre ideologues, because the isolation of these relations is the same type as they do, however, much is talked about "culture" or "power", always in an abstract way.

Another characteristic that reproduces the gender ideology is the lack of references to concrete human beings, concrete social relations. The books of the genre ideologues are full of references to other works, that is, we are in a bookish world in which a book refers to several other books (not for them extract concrete social relations, but only other theses), and a thesis refers to several other theories, a vicious and self-referential circle of ideological world. No doubt, there may be exceptions (Bourdieu does not enter in this group, for example, although his approach of concrete reality is fragmentary and reversed and he is not exactly one of the representatives of this trendency), but this is the rule of the gender ideologies.

But what is the source of Scott and gender ideologues? She herself reveals: "concern with gender as an analytic category has emerged only in the late twentieth century. It is absent from the major bodies of social theory articulated from the eighteenth to the early twentieth centuries" ${ }^{\text {"20 }}$.The use of the word occurs in a particular historical context: "The term gender is part of the attempt by contemporary feminists to stake claim to a certain definitional ground, to insist on the inadequacy of existing bodies of theory for explaining persistente inequalities bewteen women and men"21.

This mutation occurs in a "moment of great epistemological effervescence":

In the space opened by this debate and on the side of the critique of Science developed by the humanities, and of empiricism and humanism by post-structuralists, feminists have not only begun to find a theoretical voice of their own but have found scholarly and political allies as well. It is within this space that we must articulate gender as an analytic category. ${ }^{22}$

The date of the predecessor studies is the $60 \mathrm{~s}$, the time of the counterculture of the hippie movement, the feminist movement, of Betty Friedan andThe Feminine Mystique, as well as the works of Kate Millet, Sexual Politicsand Germaine Greer, The Female Eunuch, which already begin to use the term gender but without the subsequent connotation. It is from the cultural counter-revolution, Which began after the defeat of the student rebellion of May 1968 expressed in the post-avant-garde (art) and poststructuralism (science) ${ }^{23}$, that begins the ideological production which will be the basis of gender ideologies, such as the work of Michel Foucault, the largest poststructuralist ideology in his "critical" tendency and the other representatives of this ideology (Guattari, Deleuze, etc.). The ideology of gender is strengthened and systematized in the 80s. The mutation begins at the 70s: "In an article in 1973 that documents the terminological change of sex to gender, Strathern anticipates his conception of gender as a symbolic system" ${ }^{24}$.In 1988, she launched a book which deepens her conception. But it

\footnotetext{
${ }^{19}$ What we call post-structuralism is what is commonly called "postmodernism" and includes the group of emerging ideologies from the 1970s, and that became hegemonic in the following decades, including the most varied ideologies.

${ }^{20}$ Scott, 1986, p. 1066.

${ }^{21}$ Scott, 1986, p. 1066.

${ }^{22}$ Scott, 1986, p. 1066.

${ }^{23}$ Ideologically called "postmodernism". A critique of the construct "postmodernism" and a comprehensive review of post-structuralism can be seen in Viana, 2009. Another criticism of post-structuralism can be seen in Eagleton, 1998.

${ }^{24}$ Stolke, 2004, p. 91.
} 
is in the $80 \mathrm{~s}$ that feminist analysis about gender relations is more sophisticate. With the emergence of neo-liberalism, poststructuralism becomes hegemonic and dominant and the gender ideology is one of its products.

The intellectual productions from the 70s called "postmodern" are actually reformed and depoliticized versions of critical trends of the 60s. The struggles of the end of the $60 \mathrm{~s}$ (that ranges from the counterculture to the student and workers' struggles in Germany/France, and the workers' struggles in Italy, etc.) and critical intellectual production (Debord andthe Situationist International, Henri Lefebvre, Marcuse, Sartre, etc.). Capitalism's mutation occurs from the 60 s and is realized in the 80 s, with the emergence of the full regime of accumulation ${ }^{25}$, which means a cultural transformation that seeks to appropriate the previous oppositional culture to disarm it and cause it to lose strength and effect.

Poststructuralism has as its fundamental point the criticism of the approach of the whole, or, as says one of its main ideologues, of the "meta-narratives". ${ }^{26}$ It is precisely this aspect that enables the nonpoliticisation or micro-reformism, depending on the approach. Some poststructuralist, when denying all, start to perform purely descriptive approaches (non-politicisation) of everyday elements and other reference to power, but purely in everyday scale, isolating the power relations in a certain place or social relationship and after this isolation, presents isolated fights and makes its praise, refusing all forms of articulation and expansion of the fight. This procedure is used initially by Foucault ${ }^{27}$ and Guattari $^{28}$,and, afterwards is performed by gender ideologues, which create a set of constructs ahistorical and isolated, as the so-called "gender relations", and address some social phenomena creating a small world reified that references to culture and power, but taken as metaphysical entities and solely linked to this reified world.

Gender ideology arises in this context. And nothing more revealing than the vicissitudes of feminists who have embraced this concept and elect power relations as a fundamental and at the same, time hide or are unaware that these relationships are products of this same reality and therefore power relations. The "masculine domination" revealed by Bourdieu is harmless against him, perhaps by reason of being a sociologist, an intellectual, although he says that intellectuals are a "dominated fraction of the dominant class" "29. Joan Scott, Judith Butler and all others are above this "masculine" reality marked by "power relations" and they are female specimens, but do not suffer the determinations and oppression of other mortals. In a nutshell, the ideologues think they are as Baron of Munchausen and thus can be pulled by the hair and become immune to what exists (culture, power relations, phallogocentrism, male illusio, etc.). The references also have the same "immunity" and therefore Foucault, Deleuze, Guattari, are the great inspirers of the new ideology.

Thus the archeology of the term genre is only a description of its uses, but never of its genesis and its relationship with the social and historical changes. And so once again, it reproduces the evolutionary and unilinear conception of development of human thought, which occurs since Comte and Hegel, and reaches today with "ingenuous" gender ideologues. The ideology has no independent history, stand-alone ${ }^{30}$, except in the very ideological discourse, which reverses the reality and presents itself as a product of a breakthrough and improvement of the previous idea or as a false break with the predecessor conceptions, but always going towards the absolute truth.

Thus, the gender ideology is so dated historically and socially determined as any other ideology, and its ideological sources (poststructuralism) as its content, demonstrate the limits of such approach, revealing only another form of false consciousness systematized.

\section{REFERENCES}

Beauvoir, Simone 1978. O Segundo Sexo. Rio de Janeiro: Francisco Alves.

Bourdieu, Pierre 1996. As Regras da Arte. São Paulo: Companhia das Letras, 1996.

Bourdieu, Pierre 2002.Maculine Domination.Stanford: Stanford University Press.

\footnotetext{
${ }^{25}$ Viana, 2009; Viana, 2015b.

${ }^{26}$ Lyotard, 1986.

${ }^{27}$ Foucault, 1989.

${ }^{28}$ Guattari, 1981.

${ }^{29}$ Bourdieu, 1990.

${ }^{30}$ Marx and Engels, 1991.
} 
Butler, Judith 2003. Problemas de Gênero. Feminismo e Subversão da Identidade. Rio de Janeiro: Civilização Brasileira, 2003.

Eagleton, Terry 1998. As Ilusões do Pós-Modernismo. Rio de Janeiro: Jorge Zahar.

Foucault 1989, Michel. Microfísica do Poder. $8^{\text {a }}$ edition, Rio de Janeiro: Graal.

Guattari, Félix 1981. Revolução Molecular: Pulsações Políticas do Desejo. São Paulo: Brasiliense.

Lyotard, Jean-François 1986.O Pós-Moderno. Rio de Janeiro: José Olympio, 1986.

Marx, Karl and Engels, Friedrich 1982. A Ideologia Alemã (Feuerbach). $3^{\mathrm{a}}$ edition, São Paulo: Lech.

Scott, Joan 1986. Gender: A Useful Category of Historical Analysis. The American Historical Review, Vol. 91, No. 5. (Dec., 1986), pp. 1053-1075.

Stolke, Verena 2004.La Mujer es Puro Cuento: La Cultura del Género. Estudos Feministas. Vol. 12, $\mathrm{n}^{\mathrm{o}}$ 02.may/aug. 2004.

Viana, Nildo 2007.A Consciência da História. Ensaios Sobre o Materialismo Histórico-Dialético.2a edition, Rio de Janeiro: Achiamé.

Viana, Nildo 2008.Os Valores na Sociedade Moderna. Brasília: Thesaurus.

Viana, Nildo 2009. O Capitalismo na Era da Acumulação Integral. São Paulo: Ideias e Letras.

Viana, Nildo 2015a. As Esferas Sociais. A Constituição Capitalista da Divisão do Trabalho Intelectual. Rio de Janeiro: Rizoma.

Viana, Nildo 2015b. Estado, Democracia e Cidadania.A Dinâmica da Política Institucional no Capitalismo. $2^{\mathrm{a}}$ edition, Rio de Janeiro: Rizoma. 